\title{
Aspects of nitrogen and carbon cycling in the northern Bering Shelf sediment. I. The significance of urea turnover in the mineralization of $\mathrm{NH}_{4}{ }^{+}$
}

\author{
Bente Aa. Lomstein ${ }^{1}$, T. Henry Blackburn ${ }^{1}$, Kaj Henriksen ${ }^{2}$ \\ ${ }^{1}$ Department of Ecology and Genetics, University of Aarhus, DK-8000 Aarhus C, Denmark \\ ${ }^{2}$ Environmental Engineering Laboratory, University of Aalborg, Sohngaardsholmsvej 57, DK-9000 Aalborg, Denmark
}

\begin{abstract}
The impact of macrofauna on nitrogen and carbon mineralization was investigated in sediment of the shallow water Bering Sea Shelf. The main effort was focused on the probable role of macrofauna in the production of urea and the significance of urea turnover in the production of $\mathrm{NH}_{4}{ }^{+}$ Macrofaunal biomass was regulated by the quality and quantity of organic nitrogen available for degradation. This was illustrated by a low macrofaunal biomass in the sediment underlying the low productive Alaska Coastal water and a high macrofaunal biomass below the highly productive Bering Shelf/Anadyr water. A high macrofaunal biomass was correlated with high rates of urea gross production, high concentrations of urea and $\mathrm{NH}_{4}{ }^{+}$, and high sediment-water exchange rates of urea and $\mathrm{NH}_{4}{ }^{+}$. Based on a conceptual model of nitrogen mineralization in the Bering Shelf/Anadys sediment, it was suggested that urea hydrolysis could be responsible for up to $80 \%$ of the gross production of $\mathrm{NH}_{4}{ }^{+}$ The model intimated that a substantial part of the $\mathrm{NH}_{4}{ }^{+}$produced $(44 \%)$ could have been cycled within the sediment.
\end{abstract}

\section{INTRODUCTION}

The quality and quantity of organic matter sedimenting to the seafloor has an overall determining effect on benthic biomass (e.g. Grebmeier et al. 1988) and benthic mineralization (Blackburn \& Henriksen 1983, Wassmann 1984, Blackburn 1986, 1987, Graf 1988). It is generally accepted that carbon and nitrogen mineralization will eventually lead to production of $\mathrm{CO}_{2}$ and $\mathrm{NH}_{4}{ }^{+}$. These products will leave the sediment to be reutilized in the overlying water column. Depending on the oxygen conditions in the sediment surface $\mathrm{NH}_{4}{ }^{+}$ will appear as $\mathrm{NO}_{2}{ }^{-}, \mathrm{NO}_{3}{ }^{-}$and/or $\mathrm{N}_{2}$ (Blackburn 1986). It has, however, been recently stated that organic nitrogen, specifically urea, can play an important role as a nitrogenous end-product leaving the sediment (Blackburn 1987, Boucher \& Boucher-Rodoni 1988, Walsh et al. in press). Urea can be directly utilized as a nitrogen source by e.g. phytoplankton in the pelagic (Eppley et al. 1973). Bioturbation can enhance sediment mineralization processes (Kristensen \& Blackburn 1987, Aller 1988, Kristensen 1988), and macrofauna can themsel- ves be responsible for a substantial part of the total sediment respiration, 5 to $90 \%$ (Kikuchi 1986, Blackburn 1987, Emerson et al. 1988).

The purpose of this study was to elucidate possible sources of urea production, to investigate the importance of urea-turnover in the production of $\mathrm{NH}_{4}{ }^{+}$and the significance of sediment-water exchange of urea compared to the exchange of inorganic nitrogen $\left(\mathrm{NH}_{4}{ }^{+}\right.$, $\mathrm{NO}_{2}{ }^{-}, \mathrm{NO}_{3}{ }^{-}$). These measurements were evaluated in relation to macrofaunal biomass.

The investigation was divided into the following topics: the relationship between sediment quality, macrofaunal biomass, urea turnover, urea pools, $\mathrm{NH}_{4}{ }^{+}$ pools, urea and inorganic nitrogen efflux rates.

\section{MATERIALS AND METHODS}

Samples were collected from Bering Shelf sediment during 2 cruises in 1987: HX 99, June 14 to 17 on RV 'Alpha Helix' and TT 213, July 20 to August 10 on RV 'Thomas G. Thompson'. A total of 20 stations were 


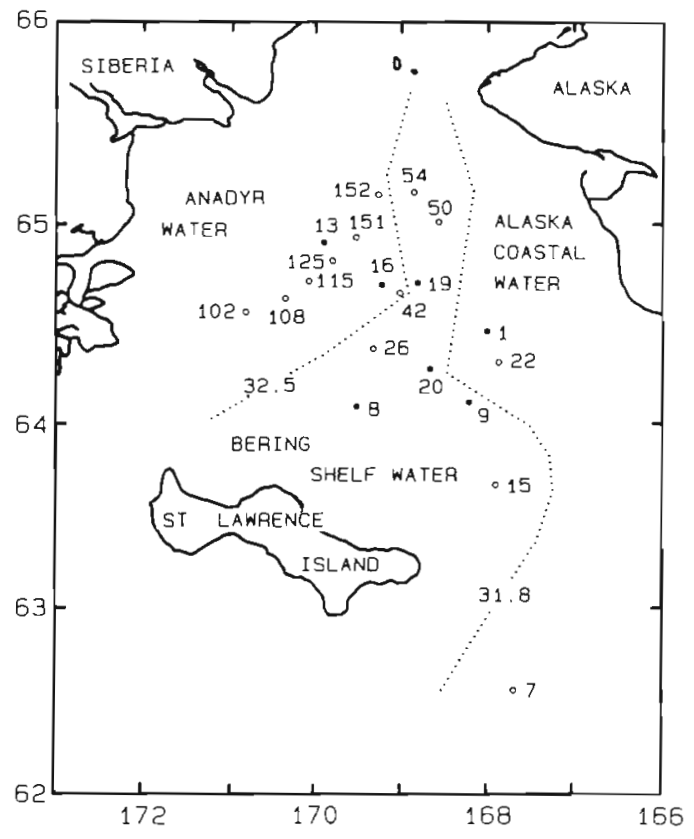

Fig. 1. Study area in the Bering Sea showing water masses and stations. : Stations on cruise HX99, June 14 to 17, 1987; stations on cruise TT213, July 20 to August 10, 1987

sampled during this period (Fig. 1). Sediment was collected using a Haps corer (Kanneworff \& Nicolaisen 1973) from which undisturbed subcores $(2.6$ and $3.6 \mathrm{~cm}$ diam.) were sampled. These cores were kept, in the dark at in situ temperatures $\left(-2^{\circ}\right.$ to $\left.+2^{\circ} \mathrm{C}\right)$ until further processing. Sediment characteristics, urea and $\mathrm{NH}_{4}{ }^{+}$ pool sizes, flux measurements and ${ }^{14} \mathrm{C}$-urea incubations were performed within 1 to $2 \mathrm{~h}$ of sampling. Bottom water was collected with a Niskin water bottle and kept in the dark at the in situ temperature until used.

Study area. The study area is located in the Bering Sea between $62^{\circ} 30^{\prime} \mathrm{N}$, in the Sphanberg Strait, and $65^{\circ} 09^{\prime} \mathrm{N}$, south of the Bering Strait (Fig. 1). The western limit is defined by the convention line, the border between the USSR and the USA. The prevailing hydrographic and biological regimes in the Bering Sea will only be discussed briefly, as they have been described extensively elsewhere (Coachman et al. 1975, Sambrotto et al. 1984, Grebmeier et al. 1988, Walsh et al in press). The water masses flowing north acorss the shallow Bering Shelf, water depth $<50 \mathrm{~m}$, can be divided into 3 main flows defined by the bottom water salinity (Walsh et al. in press). The cold Anadyr water can be distinguished from other shelf waters by a salinity $>32.5 \%$ and Bering Shelf water by the salinity range $31.8<\mathrm{S}<32.5 \%$. The warmer Alaska Coastal water, which is a mixture of Yukon river discharge and southeastern Bering Shelf water, is defined by a bottom water salinity of less than $31.8 \%$ (Fig. 1). A persistent frontal zone is established between Alaska Coastal and
Bering Shelf water during the summer months, whereas the frontal zone between Bering Shelf and Anadyr water varies in persistency and location (Grebmeier 1987). We, therefore, divided the sediment into 2 main areas characterized by the Alaska Coastal-Bering Shelf frontal zone: Bering Shelf-Anadyr sediment (BSAS) and Alaska Coastal sediment (ACS). A similar subdivision of the study area sediment was performed in the benthic macrofauna studies by Grebmeier et al. $(1988,1989)$. The average annual primary production, 1985 to 1987 , was ca 300 and $60 \mathrm{gC} \mathrm{m}^{-2}$ in Bering Shelf-Anadyr water and Alaska Coastal water, respectively (Walsh et al, in press). The salinity data, for cruise HX99, were supplied by Dr R. Highsmith and, the data for TT213, by ISHTAR Data Report No. 9 (McRoy 1987).

Sediment characteristics and biomass of macrofauna. Sediment characteristics were measured from 3 cores $(3.6 \mathrm{~cm}$ diam. $12 \mathrm{~cm}$ long). Cores were fractioned into $2 \mathrm{~cm}$ segments and those from the same depths pooled and thoroughly mixed. The specific density was determined gravimetrically on $10 \mathrm{~cm}^{3}$ portions. The porewater content $\left(\mathrm{ml} \mathrm{g}^{-1}\right)$ was determined as the weight loss from fresh sediment dried at $105^{\circ} \mathrm{C}$ for $12 \mathrm{~h}$. Sediment porosity was calculated as the specific density multiplied by the porewater content. The $\mathrm{C} / \mathrm{N}$ composition $(\mathrm{mol} / \mathrm{mol}$ ) of the sediment was determined on HCl fumed, homogenized, dried sediment in a Carlo Erba, NA $1500, \mathrm{C} / \mathrm{N}$ analyzer. The

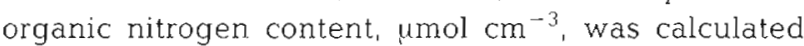
from the nitrogen content obtained in the $\mathrm{C} / \mathrm{N}$ anlysis and sediment specific density. The sediment grain size distribution was determined on dried sediment by sieving the sediment into fractions: silt + clay $<125$ um, $125<$ fine sand $<250 \mu \mathrm{m}$ and sand $>250 \mu \mathrm{m}$.

A rough biomass estimate of the dominating species of macrofauna was obtained from washing 6 to 12 cores $(3.6 \mathrm{~cm}$ diam., $10 \mathrm{~cm}$ long) through a $1 \mathrm{~mm}$ sieve screen. Animals were immediately frozen for later biomass determination. The fresh weight of the different taxa was determined on dry blotted animals in the laboratory. Fresh weight was converted to organic carbon biomass using the conversion values given in Grebmeier (1987).

Urea and $\mathrm{NH}_{4}{ }^{+}$sediment pools. The $\mathrm{NH}_{4}{ }^{+}$concentration was determined from seawater extraction of sediment. The seawater extraction was performed in order to obtain the total ionexchangeable $\mathrm{NH}_{4}{ }^{+}$concentration together with the porewater concentration of $\mathrm{NH}_{4}{ }^{+}$. The $\mathrm{NH}_{4}{ }^{+}$ionexchangeable + porewater concentration will, hereafter, be designated the total $\mathrm{NH}_{4}{ }^{+}$ concentration. Ten $\mathrm{ml}$ of inorganic, nitrogen-depleted seawater was added to $10 \mathrm{~cm}^{3}$ of homogenized sediment, mixed thoroughly and incubated at $0^{\circ} \mathrm{C}$ for $0.5 \mathrm{~h}$. The extraction was terminated by centrifugation at $2000 \times \mathrm{g}$ for $10 \mathrm{~min}$. The supernatant was immediately 
frozen for later analysis. The ionexchangeable $\mathrm{NH}_{4}{ }^{+}$ pool was extracted with seawater instead of the traditional KCl-extraction (Blackburn 1980), as the seawater extraction has been shown to give more reliable results for the $\mathrm{NH}_{4}{ }^{+}$pool in bioturbated sediments (Lomstein \& Blackburn unpubl data). Addition of high concentrations of $\mathrm{KCl}$ to the sediment can damage benthic organisms with a resultant leakage of cell fluids including $\mathrm{NH}_{4}{ }^{+}$Furthermore, Blackburn (1986) has shown that $\mathrm{K}^{+}$is not essential for the exchange of $\mathrm{NH}_{4}{ }^{+}$to occur, as $\mathrm{Na}^{+}$performs equally well. The urea concentration was, on cruise HX99, determined from seawater extractions, whereas it was determined from porewater samples on TT213. Porewater was obtained by centrifugation, in double chambered centrifuge tubes. $\mathrm{NH}_{4}{ }^{+}$was assayed by the method described in Strickland \& Parsons (1972) and urea by the diacetylmonoxime method described in Price \& Harrison (1987).

Urea turnover in the sediment. Urea turnover rates were determined in 5 cores $(2.6 \mathrm{~cm}$ diam, $12 \mathrm{~cm}$ long) from which the overlying water had been carefully removed. The plexiglass tubes were provided with selfsealing injection ports of silicone rubber at $1 \mathrm{~cm}$ intervals (Jørgensen \& Fenchel 1974). The injection of ${ }^{14} \mathrm{C}$ urea and the handling procedure was a modification of that described in Lund \& Blackburn (1989). Ten $\mu$ of

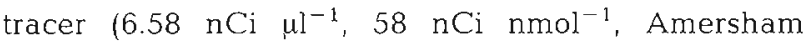
Radiochemical Center) was injected, in a line through the core, at $1 \mathrm{~cm}$ depth intervals. The enrichment of the ambient urea pool never exceeded $10 \%$ The turnover rate was measured after 2 to $3 \mathrm{~h}$ incubation in the dark at the in situ temperature. Only cores with a $100 \pm$ $20 \%$ recovery of ${ }^{14} \mathrm{C}$ were used for calculation. The turnover rate of urea was calculated by the steady state model II described in Lund \& Blackburn (1989). The turnover rate of urea, measured by the Lund and Blackburn method, is a measure of the gross production rate of urea, as the removal of the water phase during incubation prevents flux of urea into the water column. The rate of urea hydrolysis was calculated as the gross production rate of urea minus the efflux of urea from the sediment.

Macroiaunal net excretion rates of urea and $\mathrm{NH}_{4}{ }^{+}$. Net excretion rates of urea and $\mathrm{NH}_{4}{ }^{+}$from the quantitatively most important taxa of macrofauna were determined on a later cruise (Lomstein et al. unpubl data). The excretion rates were extrapolated to biomass estimates per unit area in the present study and related to exchange rates of urea and $\mathrm{NH}_{4}{ }^{+}$. The incubation conditions will only be discussed briefly, as the data will be presented elsewhere. The macrofauna taxa analyzed were Ampelisca sp. and Byblis sp. (amphipods), Macoma sp. and Nucula sp. (bivalves) and Pectinaria sp. (polychaete). Undamaged animals were incubated in bottom water from the sampling station at the in situ temperature in the dark. One or 2 controls, of bottom water alone, were incubated in each experiment. The concentration change of solutes was never allowed to exceed $20 \%$ during incubation. Measured excretion rates were corrected for differences in activity between water and sediment: Nucula sp. was $37 \%$ more active and Ampelisca sp. $25 \%$ less active in inert combusted sediment compared to water (Henriksen unpubl. data).

Net flux of $\mathrm{CO}_{2}$ urea, $\mathrm{NH}_{4}{ }^{+}$and $\mathrm{NO}_{2}{ }^{-}+\mathrm{NO}_{3}{ }^{-}$ between sediment and water. The net flux rates were measured in 4 to 6 cores ( $3.6 \mathrm{~cm}$ diam.). Sediment cores were overlaid with bottom water from the station, cores were sealed with a rubber stopper and care was taken to avoid the introduction of bubbles. The water phase was agitated with a magnet, using the incubation system described in Blackburn et al. (1988). Cores were incubated in the dark at the in situ temperature for 6 to $12 \mathrm{~h}$. The content of $\mathrm{CO}_{2}$, urea, $\mathrm{NH}_{4}{ }^{+}$and $\mathrm{NO}_{2}{ }^{-}+$ $\mathrm{NO}_{3}{ }^{-}$in the water phase, was measured at the beginning and end of the incubation. None of these concentrations changed more than $20 \%$. The concentration of $\Sigma \mathrm{CO}_{2}$ was determined by a Gran titration on $10 \mathrm{ml}$ samples, as described in Talling (1973). The concentration of $\mathrm{NO}_{2}{ }^{-}+\mathrm{NO}_{3}{ }^{-}$were measured by the method described in Strickland \& Parsons (1972).

\section{RESULTS}

\section{Sediment characteristics and biomass of macrofauna}

A summary of sediment specific density and porewater content is shown in Table 1. Data shown are average values from all stations sampled. The specific density increased from the surface down to $12 \mathrm{~cm}$, whereas the porewater content decreased with depth. The surface $\mathrm{C} / \mathrm{N}$ ratio decreased from an average of 10.9 in ACS to 8.8 in BSAS (Fig. 2a). The mean organic nitrogen content, 0 to $2 \mathrm{~cm}$, increased from 64 in ACS to $68 \mu \mathrm{mol} \mathrm{cm}{ }^{-3}$ in BSAS (Fig. 2b). The surface content of fine sand was lowest in ACS and increased towards the central part of the BSAS area (Fig. 2c).

Sediment macrofauna was dominated by amphipods throughout the study area (data not shown). The polychaetes present together with the amphipods in the ACS and eastern Bering Shelf sediment, were generally small and did not influence the total biomass significantly. However, the bivalves and polychaetes at some of the western Bering Shelf and Anadyr sediment stations, were larger and contributed to the total biomass significantly. The total macrofaunal biomass was lowest in ACS, 1.7, compared to $17.5 \mathrm{gC} \mathrm{m}^{-2}$ in the central part of the BSAS area (Fig. 2d). The macrofaunal biomass increased with decreasing $\mathrm{C} / \mathrm{N}$ ratios 
Table 1. Sediment porewater content, specific density, urea gross production rate, urea pool and $\mathrm{NH}_{4}^{+}$pool (mean values $\pm 1 \mathrm{SD}$ )

\begin{tabular}{|c|c|c|c|c|c|c|c|c|}
\hline \multirow[t]{2}{*}{$\begin{array}{l}\text { Depth } \\
(\mathrm{cm})\end{array}$} & \multirow{2}{*}{$\begin{array}{c}\text { Porewater } \\
\text { content } \\
\left(\mathrm{ml} \mathrm{g}^{-1}\right) \\
\text { BSAS }\end{array}$} & \multirow{2}{*}{$\begin{array}{c}\text { Specific } \\
\text { density } \\
\left(\mathrm{g} \mathrm{cm}^{-3}\right) \\
+\mathrm{ACS}\end{array}$} & \multicolumn{2}{|c|}{$\begin{array}{c}\text { Urea gross } \\
\text { production rate } \\
\left(\mathrm{nmol} \mathrm{cm} \mathrm{cm}^{-3} \mathrm{~d}^{-1}\right)\end{array}$} & \multicolumn{2}{|c|}{$\begin{array}{l}\text { Urea pool } \\
\left(\mathrm{nmol} \mathrm{cm}{ }^{-3}\right)\end{array}$} & \multicolumn{2}{|c|}{$\begin{array}{c}\mathrm{NH}_{4}^{+} \mathrm{pool} \\
\left(\mathrm{nmol} \mathrm{cm}{ }^{-3}\right)\end{array}$} \\
\hline & & & BSAS & $A C S$ & BSAS & ACS & BSAS & $\mathrm{ACS}$ \\
\hline $0-2$ & $0.31 \pm 0.04$ & $1.71 \pm 0.08$ & $36 \pm 26$ & $16 \pm 8$ & $6 \pm 3$ & $5 \pm 2$ & $55 \pm 41$ & $19 \pm 11$ \\
\hline $2-4$ & $0.27 \pm 0.03$ & $1.79 \pm 0.08$ & $41 \pm 25$ & $8 \pm 3$ & $7 \pm 5$ & $4 \pm 2$ & $49 \pm 24$ & $30 \pm 11$ \\
\hline $4-6$ & $0.25 \pm 0.03$ & $1.82 \pm 0.06$ & $35 \pm 12$ & $16 \pm 6$ & $5 \pm 3$ & $6 \pm 3$ & $53 \pm 25$ & $29 \pm 10$ \\
\hline $6-8$ & $0.24 \pm 0.03$ & $1.84 \pm 0.07$ & $32 \pm 14$ & $8 \pm 2$ & $5 \pm 2$ & $4 \pm 2$ & $59 \pm 30$ & $29 \pm 12$ \\
\hline $8-10$ & $0.23 \pm 0.03$ & $1.84 \pm 0.08$ & $32 \pm 19$ & $10 \pm 9$ & $6 \pm 4$ & $4 \pm 1$ & $60 \pm 31$ & $55 \pm 31$ \\
\hline $10-12$ & $0.23 \pm 0.03$ & $1.85 \pm 0.07$ & $24 \pm 14$ & $5 \pm 4$ & $5 \pm 3$ & $6 \pm 3$ & $59 \pm 34$ & $39 \pm 4$ \\
\hline
\end{tabular}
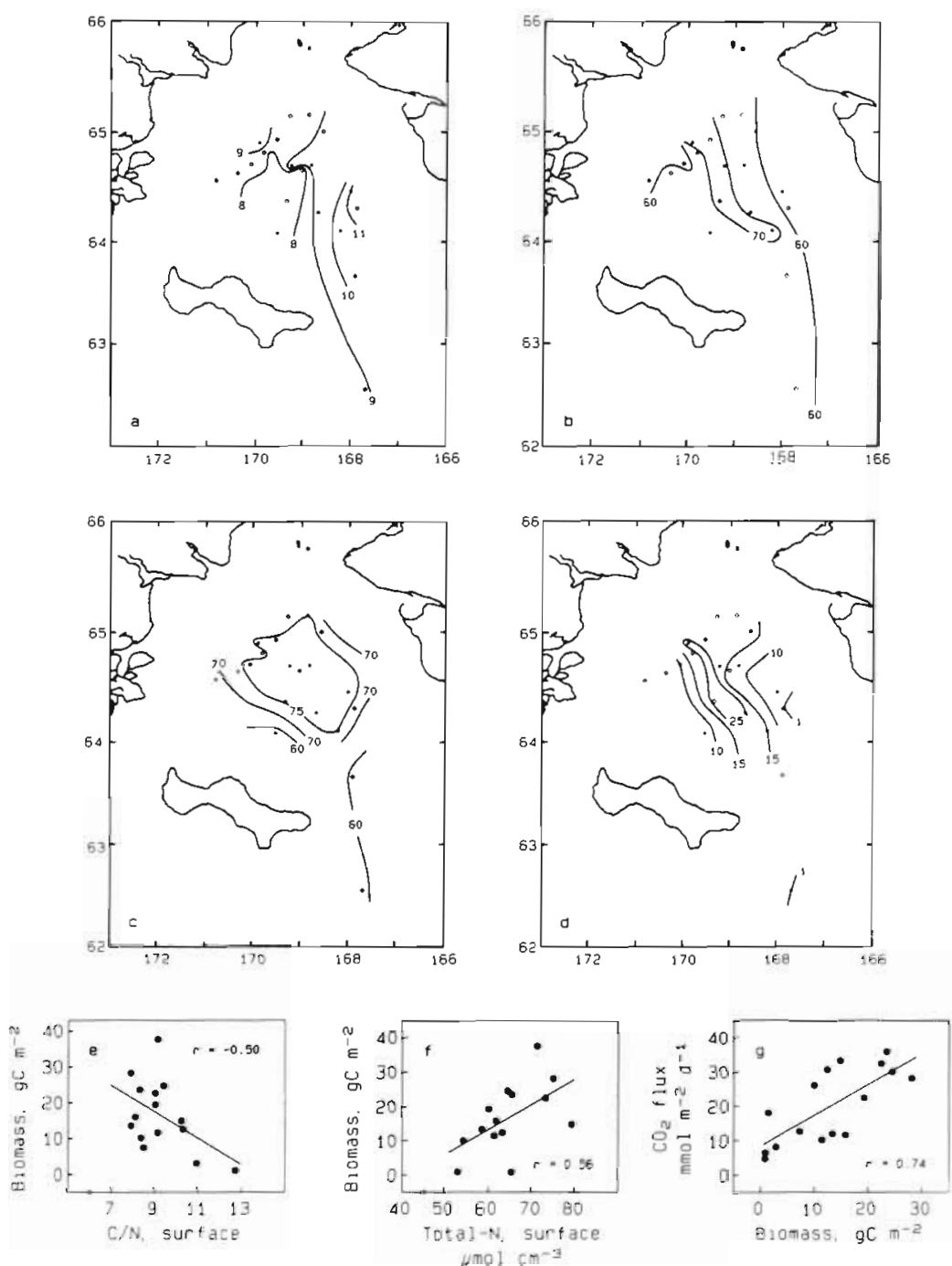

Fig. 2. Sediment characteristics and biomass of macrofauna. Isopleths of: (a) $\mathrm{C} / \mathrm{N}$ ratios in the sediment surface, 0 to $2 \mathrm{~cm}$; (b) organic nitrogen content, $\mu \mathrm{mol} \mathrm{cm}^{-3} ;$ (c) content of fine sand, \% of dry weight; (d) spatial distribution of macrofaunal biomass. $\mathrm{gC}$ $\mathrm{m}^{-2}$ Relationship between: (e) macrofaunal biomass and the $\mathrm{C} / \mathrm{N}$ ratio in the sediment surface; (f) macrofaunal biomass and the organic nitrogen content in the sediment surface; and $(\mathrm{g})$ efflux of $\mathrm{CO}_{2}$ from the sediment and macrofaunal biomass 
(Fig. 2e, $r=-0.50$ ) and with increasing content of total nitrogen in the sediment surface (Fig. 2f, $r=0.56$ ). There was a positive relationship between the rate of sediment carbon-mineralization $\left(\mathrm{CO}_{2}\right.$ efflux $)$ and macrofaunal biomass ( $\mathrm{r}=0.74$, Fig. $2 \mathrm{~g}$ ).

\section{Macrofaunal biomass and urea production}

The average gross production rate of urea in both ACS and BSAS showed high and varying rates (Table 1). The integrated, $\Sigma 0$ to $10 \mathrm{~cm}$, gross production rate of urea was lower in ACS, 1.2, compared to $3.6 \mathrm{mmol} \mathrm{N}$ $\mathrm{m}^{-2} \mathrm{~d}^{-1}$ in the central BSAS (Fig. 3a). There was an increase in the gross production rate of urea with increasing biomass of macrofauna ( $r=0.69$, Fig. 3b). The gross production rate of urea was also correlated to the $\mathrm{C} / \mathrm{N}$ ratio and the total nitrogen content in the sediment surface, since the biomass of macrofauna was related to these parameters (regressions not shown).

The mean concentration profiles of urea in ACS and BSAS were typical for bioturbated sediments (Table 1).
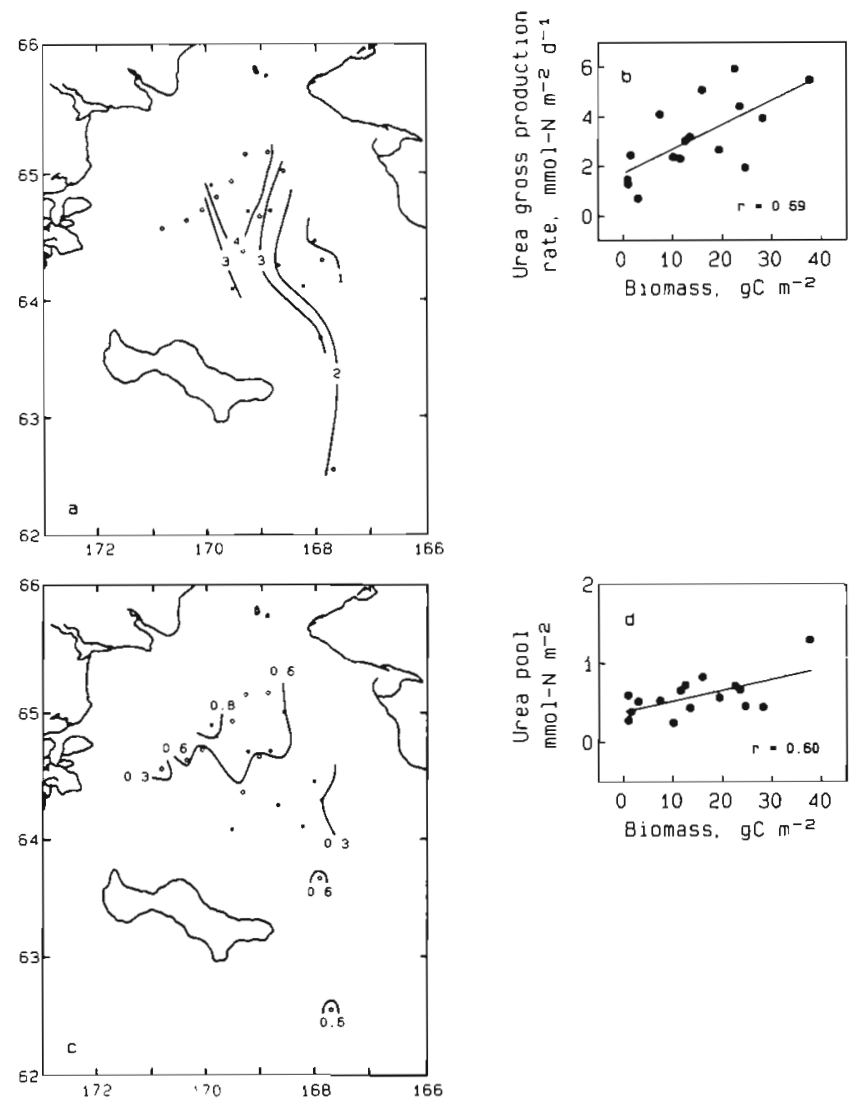

Fig. 3. Biomass and urea production. (a) Spatial distribution of integrated urea gross production rates, $\Sigma 0$ to $10 \mathrm{~cm}$, mmol $\mathrm{N} \mathrm{m}^{-2} \mathrm{~d}^{-1}$ (b) Relationship between the gross production rate of urea and the biomass of macrofauna. (c) Spatial distribution of integrated sediment urea pool, $\Sigma 0$ to $10 \mathrm{~cm}, \mathrm{mmol} \mathrm{N} \mathrm{m}^{-2}$

(d) Relationship between the urea pool and the biomass of macrofauna
The concentrations were high and varied in deeper sediment layers (Lund \& Blackburn 1989). Integrated, $\Sigma 0$ to $10 \mathrm{~cm}$, urea concentrations increased by a factor of 1.2 from ACS to BSAS (Fig. 3c). The urea pool was positively related to the biomass of macrofauna $(\mathrm{r}=$ 0.60 , Fig. 3d) and thus, also, the gross production rate of urea (not shown).

\section{Urea hydrolysis and $\mathrm{NH}_{4}{ }^{+}$}

The integrated, $\Sigma 0$ to $10 \mathrm{~cm}$, rate of urea hydrolysis mirrored the rate of urea gross production (Fig. 4 a). The average hydrolysis rate of urea was 0.43 in ACS and $2.90 \mathrm{mmol} \mathrm{N} \mathrm{m} \mathrm{N}^{-2} \mathrm{~d}^{-1}$ in BSAS. The rate of urea hydrolysis constituted $83 \%$ of the gross production rate of urea in BSAS and $37 \%$ in ACS. As the hydrolysis rate of urea was correlated with the gross production rate of urea it was also related to the macrofaunal biomass (not shown). The mean concentration profiles of $\mathrm{NH}_{4}{ }^{+}$, Table 1, were, similarly to the urea profiles, typical for bioturbated sediments (e.g. Blackburn \& Henriksen 1983). Integrated, $\Sigma 0$ to $10 \mathrm{~cm}$, total $\mathrm{NH}_{4}{ }^{+}$ concentrations increased by a factor of 1.7 from ACS to BSAS (Fig. 4 b). The average total $\mathrm{NH}_{4}{ }^{+}$concentration was 8 times higher than the concentration of urea. The $\mathrm{NH}_{4}{ }^{+}$concentration showed a positive relationship with the hydrolysis rate of urea ( $r=0.69$, Fig. $4 \mathrm{C}$ ).

\section{Biomass and sediment-water solute flux}

The flux of urea from the sediment to the water column was positive in the entire study area (Fig. 5a) and averaged $0.7 \mathrm{mmol} \mathrm{m} \mathrm{m}^{-2} \mathrm{~d}^{-1}$ in both the ACS area and BSAS area. The flux rate of $\mathrm{NH}_{4}{ }^{+}$did, however, increase considerably from ACS to BSAS (0.2 to 0.7 mmol $\mathrm{m}^{-2} \mathrm{~d}^{-1}$, Fig. 5b). The flux of urea constituted $70 \%$ of the total urea $+\mathrm{NH}_{4}^{+}+\mathrm{NO}_{2}^{-}+\mathrm{NO}_{3}^{-}$flux from the sediment to the water column in ACS and $47 \%$ in BSAS. The flux of $\mathrm{NO}_{2}{ }^{-}+\mathrm{NO}_{3}{ }^{-}$was low throughout the study area: 0.09 in ACS and $0.10 \mathrm{mmol}$ $\mathrm{m}^{-2} \mathrm{~d}^{-1}$ in BSAS (data not shown). Both the urea and $\mathrm{NH}_{4}{ }^{+}$flux were positively related to the biomass of macrofauna (Fig. 5c, d; r $=0.52$ and 0.54, respectively). Furthermore, the flux rate of urea and $\mathrm{NH}_{4}{ }^{+}$increased with increasing macrofaunal net excretion rate of the 2 solutes (Fig. 5e, f; r $=0.59$ and 0.60 , respectively).

\section{DISCUSSION}

\section{Sediment characteristics and biomass of macrofauna}

The biomass of macrofauna was greatest in area with highest quality and quantity of organic nitrogen, 

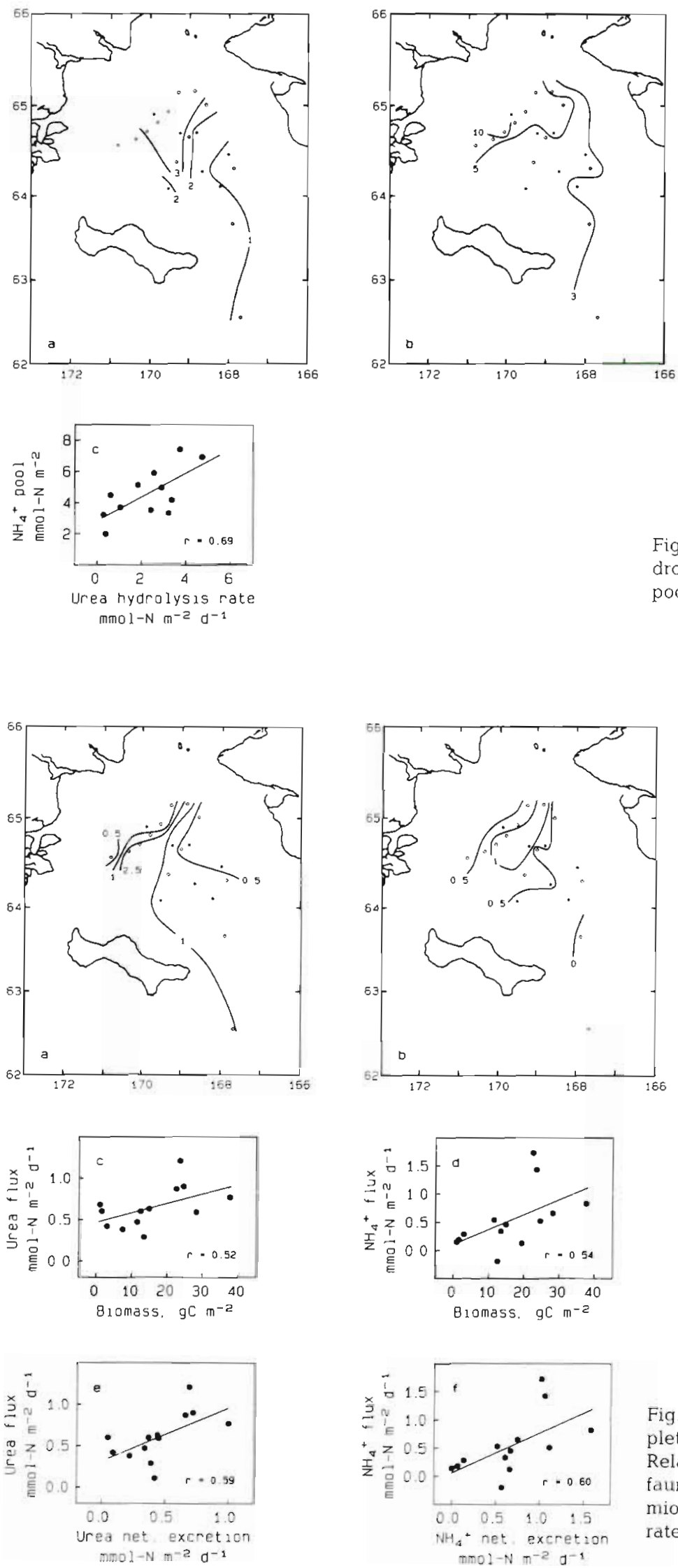

Fig. 4. Urea hydrolysis and $\mathrm{NH}_{4}^{+}$(a) Isopleth of the hydrolysis rate of urea. (b) Isopleth of the integrated $\mathrm{NH}_{4}^{+}$ pool, $\Sigma 0$ to $10 \mathrm{~cm}_{1} \mathrm{mmol} \mathrm{m} \mathrm{m}^{-2}$ (c) Relationship between the $\mathrm{NH}_{4}{ }^{+}$pool and the hydrolysis rate of urea

Fig. 5. Biomass and sediment water solute exchange. Isopleths of sediment-water flux: (a) urea and (b) $\mathrm{NH}_{4}{ }^{+}$ Relationships between: (c) flux of urea and the macrofaunal biomass; (d) flux of $\mathrm{NH}_{4}{ }^{-}$and the macrofaunal miomass; (e) urea flux and macrofaunal net urea excretion rate; (f) $\mathrm{NH}_{4}^{+}$flux and macrofaunal net $\mathrm{NH}_{4}{ }^{+}$excretion 
proven by the relationships with the $\mathrm{C} / \mathrm{N}$ ratio and the total nitrogen content in the sediment surface. The $\mathrm{C} / \mathrm{N}$ ratio was assumed to give an indication of the quality of organic matter available for degradation (Blackburn 1987, Grebmeier et al. 1988). There is, however, an obvious problem in using the $\mathrm{C} / \mathrm{N}$ ratio, the $\mathrm{C} / \mathrm{N}$ ratio itself could have been subject to rapid changes during degradation, but the $\mathrm{C} / \mathrm{N}$ ratio remained constantly low in the highly bioturbated areas. Blackburn (1987) suggested that direct macrofaunal feeding on organic detritus in the study area, may have led to less accumulation of organic carbon with a resultant low $\mathrm{C} / \mathrm{N}$ ratio. The BSAS was dominated by amphipods which was also observed by Grebmeier et al. (1989), for the same area. The number of stations, analyzed in ACS, was, however, too few to give an indication of dominating taxa. The biomass estimate for the BSAS $\left(17.5 \mathrm{gC} \mathrm{m}^{-2}\right.$, mean of 14 stations) was comparable to that obtained by Grebmeier et al. (1988) for the same area (19.1 gC $\mathrm{m}^{-2}$, mean of 21 stations), but the biomass estimate for $\operatorname{ACS}\left(1.7 \mathrm{gC} \mathrm{m}^{-2}\right.$, mean of 3 stations) was low compared to other estimate $\left(6.2 \mathrm{gC} \mathrm{m}^{-2}\right.$, mean of 12 stations, Grebmeier et al. 1988). The lower value might be due to the few stations sampled and to a small sediment area sampled per station. Our sampling scheme was limited by sampling only 60 to $120 \mathrm{~cm}^{2}, 10 \mathrm{~cm}$ depth, compared to the $4000 \mathrm{~cm}^{2}$ sediment area covered by Grebmeier et al. (1988). The small sample size might have affected the biomass estimate, mostly at stations with low biomass. Both sampling procedures did, however, have a weakness in not capturing the deepdwelling taxa. This problem was also recognized by Grebmeier et al. (1989).

\section{Macrofaunal biomass and urea production}

Macrofauna were probably responsible for most urea production (Fig. 3b) but urea concentration and turnover could also be correlated with organic nitrogen availability ( $\mathrm{C} / \mathrm{N}$ ratios). It is, however, likely that the quantity and quality of organic nitrogen were fundamental factors determining the overall differences in urea gross production between stations, since the macrofaunal biomass was also dependent on these parameters.

There were some weaknesses inherent in the method used to measure macrofaunal excretion: (1) removal of animals from their natural environment can cause stress; (2) exclusion of food sources during incubation is likely to cause a reduced metabolic and excretory activity; and (3) part of the measured net $\mathrm{NH}_{4}{ }^{+}$excretion could be a product of urea excreted and hydrolyzed during incubation. We believe that the first problem has been partially solved by correcting excretion rates to rates obtained in inert combusted sediment. The correction factor used for Nucula sp. was similar to that reported by Follum \& Gray (1987) for Nucula tenuis. The measured excretion rate of urea constituted 12 and $3 \%$ in BSAS and ACS, respectively, of the gross production rate of urea. Due to the second problem, we expect the measured excretion rates to represent minimal estimates for in situ rates. Follum \& Gray (1987) showed that the resting excretion rate of $N$. tenuis was ca $55 \%$ of the excretion rate immediately after feeding. If urea was hydrolyzed to $\mathrm{NH}_{4}{ }^{+}$during incubation this would have led to an even more severe underestimation of urea excretion.

Sediment microbial activity can be enhanced in a number of different ways due to bioturbation (e.g. Aller 1988, Kristensen 1988). Among these effects are: (1) downwards mixing of newly sedimented organic matter to deeper sediment strata by burrowing activites (Hylleberg \& Henriksen 1980, Aller 1982, Kanneworff \& Christensen 1986, Kristensen 1988). (2) Increased flux of oxygen and mineralization products across the sediment-water interface (Sørensen et al. 1979. Henriksen et al. 1983, Kristensen 1984, 1985). (3) Fecal pellet formation can provide new sites for colonization by microorganisms (Hargrave 1970, 1975, Henriksen et al. 1983, Kristensen 1988). (4) Burrow linings can provide sites of enhanced bacterial production (Aller et al. 1983, Henriksen et al. 1983, Kikuchi 1986, Henriksen \& Kemp 1988, Reichardt 1988), bacterial and meiofaunal populations (Aller 1988, Kristensen 1988) and high levels of hydrolytic enzymes (Reichardt 1988). The general stimulatory effect of macrofauna on sediment mineralization processes was illustrated by the positive relationship between net carbon oxidation rates $\left(\mathrm{CO}_{2}\right.$ flux) and the biomass of macrofauna. We suggest that urea was produced from macrofaunal excretion and possibly by other organisms (bacteria and/or microand meio-fauna) found in this type of sediment. Gray (1985) has shown that meiofaunal $\mathrm{NH}_{4}{ }^{+}$excretion is significant in $\mathrm{NH}_{4}^{+}$production.

\section{Urea hydrolysis and $\mathrm{NH}_{4}{ }^{+}$}

Macrofaunal biomass was related to urea hydrolysis rates, since macrofauna produced urea and provided habitats for optimal activity of both urea hydrolyzing bacteria and extracellularly bound urease (in burrow walls and fecal pellets). There was good agreement between the rate of urea hydrolysis and urea gross production in the study area. A high percentage of urea was hydrolyzed in BSAS (83\% of production). This was not the case in ACS, since only $37 \%$ of the urea produced was hydrolyzed to $\mathrm{NH}_{4}{ }^{+}$and $\mathrm{CO}_{2}$. However, the correlation between the rate of urea hydrolysis and 
the $\mathrm{NH}_{4}{ }^{+}$pool indicate that urea hydrolysis was an important source of $\mathrm{NH}_{4}{ }^{+}$This has been suggested earlier for the Bering-Chukchi Seas sediment (Blackburn 1987). It is, however, well-known from studies of other sediment processes, that macrofaunal burrowing activity can enhance coupling between processes (Aller 1988, Kristensen 1988). Further, Reichardt (1988) demonstrated that burrow walls contained higher concentrations of certain hydrolytic enzymes (alkaline phosphatase and sulfatase) than the surrounding sediment.

Urease activity has been demonstrated in more than 200 species of bacteria including both Gram-positives and Gram-negatives (McLean et al. 1988). Among these were aerobic, microaerophilic, facultatively anaerobic and anaerobic bacteria (Gibbons \& Doetsch 1959, Ladd \& Jackson 1982, McLean et al. 1988). It is generally accepted that bacteria use $\mathrm{NH}_{4}{ }^{+}$preferentially to urea, as a nitrogen source, when both are available (Kaltwasser et al. 1972, Zorn et al. 1982, Jahns et al. 1988, McLean et al. 1988). Urease is a noninducible enzyme and its activity has been found to be regulated in conjunction with other nitrogen assimilatory enzymes (McLean et al. 1988). Considering the high concentration of $\mathrm{NH}_{4}{ }^{+}$, compared to urea in the study area, it is not likely that bacteria hydrolyzed urea to obtain $\mathrm{NH}_{4}{ }^{+}$for incorporation into cell biomass. Another possible role of urea hydrolysis in bacteria might be to maintain an elevated extracellular $\mathrm{pH}$ (Stanier et al. 1980, Gruninger \& Goldman 1988, McLean et al. 1988). The hydrolysis of urea and following excretion of $\mathrm{NH}_{3}$ is accompanied by a considerable increase in $\mathrm{pH}$, since $2 \mathrm{~mol} \mathrm{NH}_{3}$ are formed per mol of urea decomposed. However, studies in soil have demonstrated that only part of the urease activity can be ascribed to microbes. The remainder of the activity was in the cell free humus fraction (McLaren \& Pukite 1972), immobilized on clay-organic matter complexes by hydrophobic bonding (Ladd \& Jackson 1982, Boyd \& Mortland 1985) and to polysaccharides as well as linked to aromatic polymers (Ladd \& Jackson 1982). Burns (1982) suggested that the binding of enzyme to soil particulates may enhance the rigidity of enzyme structures, thus protecting them against denaturation. Further, binding may keep enzyme inaccessible to proteinases but not to smaller-sized substrate.

\section{Biomass and sediment-water solute flux}

Macrofauna played an important, direct role in the sediment-water solute flux, by excretion and transport of solutes, by ventilation and/or, by enhancing the sediment-water interface. It is only recently that the relationship between benthic macrofauna and urea flux has been studied. A few preliminary data from the Bering-Chukchi Seas have shown the flux of urea to be high in areas with a high macrofaunal biomass (Blackburn 1987). The stimulatory effect of macrofaunal activity on $\mathrm{NH}_{4}{ }^{+}$flux has been demonstrated in a wide variety of benthic communities (Henriksen et al. 1980, Henriksen et al. 1983, Doering et al. 1987, Andersen \& Kristensen 1988, Kristensen 1988). Assuming that the measured excretion rates were correct, the excretion of urea could account for $66 \%$ of the total urea efflux in BSAS and $4 \%$ in $\mathrm{ACS}$, whereas the excretion of $\mathrm{NH}_{4}{ }^{+}$ accounted for $100 \%$ of the $\mathrm{NH}_{4}{ }^{+}$efflux in BSAS and $23 \%$ in ACS. This implies that macrofaunal excretion was a major source of urea and $\mathrm{NH}_{4}{ }^{+}$flux in BSAS, whereas other sources of urea production and subsequent mineralization to $\mathrm{NH}_{4}{ }^{+}$were major sources in ACS. Earlier studies by Kristensen (1984) and Henriksen et al. (1983) support this conclusion, as they found benthic macrofaunal excretion to be responsible for a major part of $\mathrm{NH}_{4}{ }^{+}$flux in bioturbated areas.

The present study demonstrated that the flux of urea constituted an important part of the total urea $+\mathrm{NH}_{4}{ }^{+}$ $+\mathrm{NO}_{2}{ }^{-}+\mathrm{NO}_{3}{ }^{-}$flux from the sediment to the water column (mean $47 \%$ in BSAS and $70 \%$ in ACS). Few studies have considered the importance of dissolved organic nitrogen (DON) efflux, across the sedimentwater interface (Nixon et al. 1975, Enoksen \& RüdénBerg 1983, Nixon \& Pilson 1983, Enoksen 1987, Hopkinson 1987, Boucher \& Boucher-Rodoni 1988, Teague et al. 1988). The DON flux has been reported to be both relatively unimportant compared to the flux of inorganic nitrogen, $\approx 10 \%$ (Nixon \& Pilson 1983, Hopkinson 1987) and to approximate or exceed the flux of $\mathrm{NH}_{4}{ }^{+}$(Nixon et al. 1975, Enoksen \& Rüdén-Berg 1983, Enoksen 1987, Boucher \& Boucher-Rodini 1988). The DON flux measured by Boucher \& Boucher-Rodoni (1988) comprised urea and primary amines. They concluded that urea played an important role, seasonally, as a nitrogeneous end-product in sediment mineralization.

\section{Nitrogen cycling in the Bering Shelf/Anadyr sediment: a conceptual model}

Further discussion will be related to Fig. 6, in which the measured and calculated rates can be seen in relation to each other. The discussion will be restricted to data obtained in BSAS, as these are based on the greatest number of observations. The production of $\mathrm{NH}_{4}{ }^{+}$by the benthic fauna, either by direct excretion, or via urea hydrolysis was $3.6 \mathrm{mmol} \mathrm{m}^{-2} \mathrm{~d}^{-1}$ Only 2.0 mmol $\mathrm{m}^{-2} \mathrm{~d}^{-1}$ of this $\mathrm{NH}_{4}{ }^{+}$effluxed to the overlying water $\left(\mathrm{NH}_{4}^{+}+\mathrm{NO}_{2}^{-}+\mathrm{NO}_{3}^{-}+\mathrm{N}_{2}\right)$. Previously measured denitrification rates from the same area 


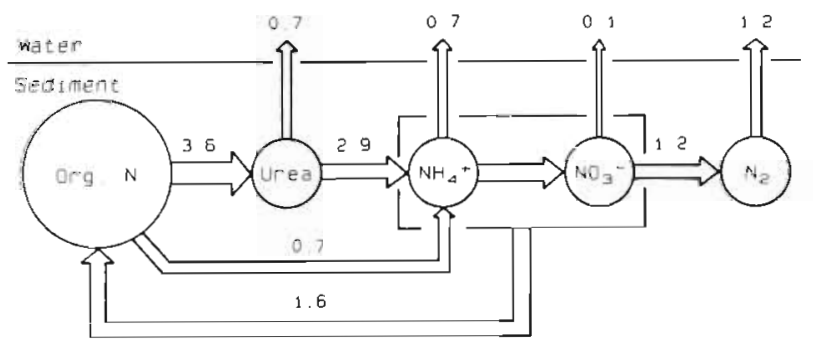

Fig. 6. Nitrogen budget for Bering Shelf/Anadyr sediment (BSAS). Rates are given in mmol $\mathrm{N} \mathrm{m}^{-2} \mathrm{~d}^{-1}$

amounted to ca $1.2 \mathrm{mmol} \mathrm{m} \mathrm{m}^{-2} \mathrm{~d}^{-1}$ (Henriksen et al. unpubl. data). There was thus a need to explain what had happened to the remaining $1.6 \mathrm{mmol} \mathrm{m} \mathrm{m}^{-2} \mathrm{~d}^{-1}$. Our proposal is that this surplus $\mathrm{NH}_{4}{ }^{+}$was incorporated into microbial biomass. There is a limit to how much bacterial biomass could have been accumulated and it therefore seemed reasonable to suggest that microbial cells were either eaten by the benthic fauna, autolyzed or exported from the sediment by an unknown mechanism. Mineralization within the sediment would have resulted in a closed cycle of alternate organic nitrogen degradation and resynthesis, driven by carbon oxidation. To obtain net assimilation of $\mathrm{NH}_{4}{ }^{+}$, the substrate must have had a $\mathrm{C} / \mathrm{N}$ ratio $>12$, given a carbon assimilation efficiency of 0.5 and a $\mathrm{C} / \mathrm{N}$ ratio in cells of 6/1 (Blackburn 1980). The $\mathrm{C} / \mathrm{N}$ ratio in the sediment organic matter was always less than 12 , but some sediment components were probably depleted in nitrogen. For example animal feces could have had a low nitrogen content due to preferential nitrogenmineralization (Kristensen \& Blackburn 1987). Further, animal secretions in burrow linings (e.g. mucus) presumably had a low nitrogen content. The interrelationship between fauna and microbes is somewhat analogous to that between a rumniant and its resident flora. In both situations inorganic nitrogen $\left(\mathrm{NH}_{4}{ }^{+}\right)$is incorporated into microbial biomass which again serves as a protein source for the animal.

Acknowledgements. We are grateful to the following people for their excellent support and assistance during the study: $\mathrm{S}$. Andreassen, T. Wiegers, D. Olsson (field and laboratory assistance) and E. Glob (scientific assistance). E. Lomstein provided valuable comments on the manuscript. Additional shiptime was generously provided by Dr R. Highsmith, University of Alaska. We also appreciate the assistance from the captains and crews for the RV 'Alpha Helix' and the RV 'Thomas G. Thompson' Financial support was provided through the ISHTAR project by grant DPP-B605659 from the Division of Polar Programs, National Science Foundation.

\section{LITERATURE CITED}

Aller, R. C. (1982). The effects of macrobenthos on chemical properties of marine sediment and overlying water. In:
McCall, P. L., Tevesz, M. J. S. (eds.) Animal-sediment relations. Plenum Publ. Comp., New York, p. 53-102

Aller, R. C. (1988). Benthic fauna and biogeochemical processes in marine sediments: the role of burrow structures. In: Blackburn, T H., Sørensen, J. (eds.) SCOPE Symposium, Nitrogen Cycling in Coastal Marine Environments. John Wiley and Sons, London, p. 301-338

Aller, R. C., Yingst, J. Y., Ullman, W. J. (1983). Comparative biogeochemistry of water in intertidal Onuphis (polychaeta) and Upogebia (crustacea) burrows: temporal patterns and causes. J. mar. Res. 41: 571-604

Andersen, F. Ø., Kristensen, E. (1988). The influence of macrofauna on estuarine benthic community metabolism: a microcosm study. Mar. Biol. 99: 591-603

Blackburn, T. H. (1980). Seasonal variations in the rate of organic- $\mathrm{N}$ mineralization in anoxic marine sediments. In: Biogeochimie de la matière organique a l'interface eausediment marin, Edition du CNRS, Paris, p. 173-183

Blackburn, T. H. (1986). Microbial processes of $\mathrm{N}$ - and $\mathrm{C}$ cycles in marine sediments. In: Megusár, F., Gantar, M. (eds.) Microbial ecology. Slovene Society for Microbiology, Ljublijana, p. 218-224

Blackburn, T. H. (1987). Microbial food webs in sediments. In: Sleigh, M. A. (ed.) Microbes in the sea. Ellis Horwood, Chichester, p. 39-58

Blackburn, T. H., Henriksen, K. (1983). Nitrogen cycling in different types of sediments from Danish waters. Limnol. Oceanogr 28: 477-493

Blackburn, T H., Lund, B. Aa., Krom, M. D. (1988). C- and Nmineralization in the sediments of earthen marine fishponds. Mar. Ecol. Prog. Ser 44: 221-227

Boucher, G., Boucher-Rodoni, R. (1988). In situ measurement of respiratory metabolism and nitrogen fluxes at the interface of oyster beds. Mar. Ecol. Prog. Ser. 44: 229-238

Boyd, S. A., Mortland, M. M. (1985). Urease activity on a clayorganic complex. Soil Sci. Soc. Am. J. 49: 619-622

Burns, R. G. (1982). Enzyme activity in soil: location and a possible role in microbial ecology. Soil Biol. Biochem. 14: $423-427$

Coachman, L. K., Aagaard, K., Tripp, R. B. (1975). Bering Strait: the regional oceanography. Univ. Wash. Press, Seattle

Doering, P. H., Kelly, J. R., Oviatt, C. A., Sowers, T. (1987). Effect of the hard clam Mercenaria mercenaria on benthic fluxes of inorganic nutrients and gases. Mar. Biol. 94 $377-383$

Emerson, C. W., Minchinton, T. E., Grant, J. (1988). Population structure, biomass and respiration of $M y a$ arenaria $L$. on temperate sandflat. J. exp. mar. Biol. Ecol. 115: 99-111

Enoksson, V. (1987). Nitrogen flux between sediment and water and its regulatory factors in coastal areas. $\mathrm{Ph} . \mathrm{D}$. dissertation, Dept. Mar. Microbiol., Univ. Göteborg, Sweden

Enoksson, V., Rüdén-Berg, L. (1983). A system for determining exchanges between sediment and water exemplified by nitrogen flux under controlled oxygen conditions. Hallberg, R. (ed.) Environmental Biogeochemistry. Ecol. Bull., Stockholm, 35: 243-250

Eppley, R. W., Renger, E. H., Venrick, E. L., Mullin, M. M. (1973). A study of plankton dynamics and nutrient cycling in the central gyre of the North Pacific Ocean. Limnol. Oceanogr. 18: 534-551

Follum, O. A., Gray, J. S. (1987). Nitrogenous excretion by the sediment-living bivalve Nucula tenuis from the Oslofjord, Norway. Mar. Biol. 96: 355-358

Gibbons, R. J., Doetsch, R. N. (1959). Physiological study of an obligately anaerobic ureolytic bacterium. J. Bact. 77: $417-428$ 
Graf, G. (1988). Die Reaktionen des Benthals auf den saisonalen PartikelfluB und die laterale Advektion sowie deren Bedeutung für Sauerstoff- und Kohlenstoffbilanzen Habilitationsschrift der mathematisch-naturwissenschaftlichen Fakultät der Christian-Albrecht-Universität zu Kiel. F.R.D.

Gray, J. S. (1985). Nitrogeneous excretion by meiofauna from coral reef sediments: Mecor 5' Mar Biol. 89: 31-35

Grebmeier, J. M. (1987). The ecology of benthic carbon cycling in the northern Bering and Chukchi Seas. Ph. D. dissertation, Inst. Mar. Sci., Univ. Alaska, Fairbanks

Grebmeier, J. M., Feder, H. M., McRoy, C. P. (1989). Pelagicbenthic coupling on the shelf of the northern Bering and Chukchi Seas. II. Benthic community structure. Mar. Ecol Prog. Ser. 51. 253-268

Grebmeier, J. M., McRoy, C. P., Feder, H. M. (1988). Pelagicbenthic coupling on the shelf of the northern Bering and Chukchi Seas. I. Food supply source and benthic biomass. Mar. Ecol. Prog. Ser. 48: 57-67

Gruninger, S. E., Goldman, M. (1988). Evidence for urea cycle activity in Sporocarcina ureae. Archs Microbiol. 150 394-399

Hargrave, B. T (1970). The effect of a deposit-feeding amphipod on the metabolism of benthic microflora. Limnol. Oceanogr. 15: 21-30

Hargrave, B. T (1975). The central role of invertebrate faeces in sediment decomposition. In: Anderson, J. M., Macfacyen, A. (eds.) The role of terrestrial and aquatic organisms in decomposition processes. The 17 th Symposium of the British Ecology Society. Blackwell Scientific Publications, Oxford, p. 301-321

Henriksen, K., Hansen, J. I., Blackburn, T H. (1980). The influence of benthic infauna on exchange rates of inorganic nitrogen between sediment and water. Ophelia (Suppl.) 1. 249-256

Henriksen, K., Kemp, W M. (1988). Nitrification in estuarine and coastal marine sediments. In: Blackburn, T H., Sorensen, J. (eds.) SCOPE Symposium, Nitrogen Cycling in Coastal Marine Environments. John Wiley and Sons, London, p. 175-190

Henriksen, K., Rasmussen, M. B., Jensen, A. (1983). Effect of bioturbation on microbial nitrogen transformations in the sediment and fluxes of ammonium and nitrate to the overlying water Hallberg, R. (ed.) Environmental biogeochemistry. Ecol. Bull., Stockholm, 35: 193-205

Hopkinson Jr., C. S. (1987). Nutrient regeneration in shallowwater sediments of the estuarine plume region of the nearshore Georgia Bight, USA. mar Biol. 94: 127-142

Hylleberg, J., Henriksen, K. (1980). The central role of bioturbation in sediment mineralization and element re-cycling. Ophelia (Suppl.) 1: 1-16

Jahns, T., Zobel, A., Kleiner, D., Kaltwasser, H. (1988). Evidence for carrier-mediated, energy-dependent uptake of urea in some bacteria. Archs Microbiol. 149: 377-383

Jørgensen, B. B., Fenchel, T. (1974). The sulfur cycle of a marine sediment model system. Mar. Biol. 24: 189-201

Kaltwasser, H., Kramer, J., Conger, W. R. (1972). Control of urease formation in certain aerobic bacteria. Archs Microbiol. 81. 178-196

Kanneworff, E., Christensen, H. (1986). Benthic community respiration in relation to sedimentation of phytoplankton in the Øresund. Ophelia 26: 269-284

Kanneworff, E., Nicolaisen, W (1973). The "Haps" a framesupported bottom corer. Ophelia 10: 119-129

Kikuchi, E. (1986). Contribution of the polychaete, Neanthes japonica (Izuka), to the oxygen uptake and carbon dioxide production of an intertidal mud-flat of the Nanakita River estuary, Japan. J. exp. mar. Biol. Ecol. 97: 81-93

Kristensen, E. (1984). Effect of natural concentrations on nutrient exchange between a polychaete burrow in estuarine sediment and the overlying water. J. exp. mar Biol. Ecol 75: $171-190$

Kristensen, E. (1985). Oxygen and inorganic nitrogen exchange in a Nereis virens (Polychaeta) bioturbated sediment-water system. J. Coast. Res. 1: 109-116

Kristensen, E. (1988). Benthic fauna and biogeochemical processes in marine sediments: microbial activities and fluxes. In: Blackburn, T H., Sørensen, J. (eds.) SCOPE Symposium, Nitrogen Cycling in Coastal Marine Environments. John Wiley and Sons, London, p. 275-299

Kristensen, E., Blackburn. T H. (1987). The fate of organic carbon and nitrogen in experimental marine sediment systems: Influence of bioturbation and anoxia. J. mar. Res. 45: 231-257

Ladd, J. N., Jackson, R. B. (1982). Biochemistry of ammonification. In: Stevenson, F. J. (ed.) Agronomy no. 22, American Society of Agronomy, Inc Madison, Wisconsin, USA, p $173-228$

Lund, B. Aa., Blackburn, T. H. (1989). Urea turnover in a coastal marine sediment measured by a ${ }^{14} \mathrm{C}$-urea short term incubation. J. microbiol. Meth. 9: 297-308

McLaren, A. D., Pukite, A. (1972). Ubiquity of some soil enzymes and isolation of soil organic matter with urease activity. Proc. int. Meet. Humic Substances, Nieuwersluis, Pudoc, Wageningen, p. 187-193

McLean, R. J. C., Nickel, J. C., Cheng, K.-J., Costerton, J. W (1988). The ecology and pathogenicity of urease-producing bacteria in the urinary tract. CRC critical Rev. Microbiol. 16:37-79

McRoy, C. P. (1987). ISHTAR Data Report No. 9. Hydrographic Data, STD, Nutrient, \& Chlorophyll. Inst. Mar. Sci., Univ. Alaska, Fairbanks

Nixon, S. W., Oviatt, C. A., Hale, S. S. (1975). Nitrogen regeneration and the metabolism of coastal marine bottom communities. In: Anderson, J. M., Macfadyen, A. (eds.) The Role of Terrestrial and Aquatic Organisms in Decomposition Processes. The $17 \mathrm{th}$ Symposium of the British Ecological Society. Blackwell Scientific Publications, Oxford p. 269-283

Nixon, S. W. Pilson, M. E. Q. (1983). Nitrogen in estuarine and coastal marine ecosystems. In: Carpenter, E. J., Capone, D. G. (eds.) Nitrogen in the Marine Environment. Academic Press, New York p. 565-648

Price, N. M., Harrison, P. J. (1987). Comparison of methods for the analyses of dissolved urea in seawater. mar Biol. 94: $307-317$

Reichardt, W. (1988). Impact of bioturbation by Arenicola marina on microbiological parameters in intertidal sediments. Mar Ecol. Prog. Ser. 44: 149-158

Sambrotto, R. N., Goering, J. J., McRoy, C. P. (1984). Large Yearly production of phytoplankton in the Westem Bering Strait. Science 225: 1147-1150

Sørensen, J., Jørgensen, B. B., Revsbech, N. P. (1979). A comparison of oxygen, nitrate and sulfate respiration in coastal marine sediments. Microb. Ecol. 5: 105-115

Stanier, R. Y., Adelberg, E. A., Ingraham, J. L. (1980). General microbılogy, Athedn. MacMillan Press, London, Basingstoke

Strickland, J. D. H., Parson, T R. (1972). A practical handbook of sea water analysis. Bull. Fish. Res. Bd Can.

Talling, J. F. (1973). The application of some electrochemical methods to the measurement of photosynthesis and respiration in fresh waters. Freshwat. Biol. 3: 335-362 
Teague, K. G., Madden, C. J., Day Jr, J. W. (1988). Sedimentwater oxygen and nutrient fluxes in river-dominated estuary. Estuaries 11: 1-9

Walsh, J. J., McRoy, C. P., Coachman, L. K., Goering, J. J., Nihoul, J. J., Whitledge, T E., Blackburn, T. H., Parker, P. L., Wirick, C. D., Shuert, P. G., Grebmeier, J. M., Springer, A. M., Tripp, R. D., Hansell, D. A., Djenidi, S., Deleersnijder, E., Henriksen, K., Lund, B. Aa., Andersen, P., Muller-Karger, F. E., Dean, K. (in press). Carbon and

This article was submitted to the editor nitrogen cycling within the Bering/Chukchi Seas: source regions for organic matter effecting AOU demands of the Arctic Ocean. Prog. Oceanogr

Wassmann, P. (1984). Sedimentation and benthic mineralization of organic detritus in a Norwegian fjord. Mar Biol. 83: $83-94$

Zorn, C., Dietrich, R., Kaltwasser, H. (1982). Regulation by repression of urease biosynthesis in Proteus rettgeri. Z. allg. Mikrobiol. 22: 197-203

Manuscript first received: June 13, 1989

Revised version accepted: August 7, 1989 